\title{
The political ontology of climate change: moral meteorology, climate justice, and the coloniality of reality in the Bolivian Andes
}

\author{
Anders Burman ${ }^{1}$ \\ Lund University, Sweden
}

\begin{abstract}
Taking Boaventura de Sousa Santos' argument that there is no global social justice without global cognitive justice as its starting point, this article suggests that there is no global climate justice without global cognitive justice (implying both ontological justice and epistemological justice). If we take "the ontological turn" in anthropology and other disciplines and its focus on indigenous ontologies seriously, however, we seem to end up in a situation that is difficult to maneuver in relation to conventional understandings of climate justice. When discussing climate change in relation to multiple ontologies, there are two risks: 1) reproducing what I call "the coloniality of reality", arguing that indigenous ontologies are actually nothing but a cultural (mis-) representation of the world; 2) reproducing a conservative relativism that leads to nothing but the maintenance of status quo and that bears a resemblance to climate change denial. A thorough ethnographic understanding of what I would call "the moral meteorology" of the Andes and a broadened understanding of climate change, however, make it possible to navigate between the Scylla of coloniality and the Charybdis of relativism and to articulate a radical critique of fossil-fueled capitalism from a relational ontology, demanding climate justice while denouncing coloniality, and discussing the political ontology of climate change without ignoring its political ecology - and vice versa.
\end{abstract}

Key words: Coloniality; climate justice; cognitive justice; political ontology; political ecology; Aymara.

\section{Résumé}

Prenant l'argument de Boaventura de Sousa Santos selon lequel il n'existe pas de justice sociale globale sans la justice cognitive globale, cet article suggère qu'il n'y a pas de justice climatique mondiale sans justice cognitive globale (impliquant à la fois la justice ontologique et la justice épistémologique). Si nous prenons «le tournant ontologique» dans l'anthropologie et d'autres disciplines et que nous mettons l'accent sur les ontologies autochtones au sérieux, nous semblons finir dans une situation difficile par rapport à la compréhension conventionnelle de la justice climatique. Lorsqu'on parle du changement climatique par rapport aux multiples ontologies, il existe deux risques: 1) reproduire ce que j'appelle «la colonialité de la réalité», arguant que les ontologies autochtones ne sont en réalité qu'une culture (une mauvaise représentation du monde) et 2 ) Reproduisant un relativisme conservateur qui ne conduit qu'à l'entretien du statu quo, se rapprochant du déni du changement climatique. Une compréhension ethnographique approfondie de ce que j'appelle «la météorologie morale» des Andes et une compréhension élargie du changement climatique permet cependant de naviguer entre la Scylla de la colonisation et les Charybdis du relativisme et d'articuler une critique radicale des fossiles, A alimenté le capitalisme. Cela diffère d'une ontologie relationnelle - exigeant la justice climatique tout en dénonçant la colonialité et en discutant de l'ontologie politique du changement climatique sans ignorer son écologie politique - et vice versa.

Mots clés: colonisation; La justice climatique; La justice cognitive; Ontologie politique; Écologie politique; Aymara.

1 Dr. Anders Burman, Associate Professor, Human Ecology Division, Lund University, Sweden. Email: anders.burman@hek.lu.se, anders.burman@globalstudies.gu.se. Acknowledgements: I am profoundly thankful to Carlos Yujra for sharing his knowledge with me during all these years. Likewise, I thank La Escuela de Pensamiento Pacha in El Alto and I gratefully acknowledge the help received and the knowledge shared by climate activists in La Paz. For critical and fruitful comments on earlier drafts of this article, I thank Dan Rosengren, Stefan Permanto, Karsten Paerregaard, my students at the Human Ecology Division at Lund University, and two anonymous reviewers. The research upon which this article is based was funded by the Swedish Foundation for Humanities and Social Sciences. 


\section{Resumen}

El artículo parte del argumento de Boaventura de Sousa Santos en cuanto se refiere a que no habrá justicia social global sin justicia cognitiva global. Así, el artículo plantea que no habrá una justicia climática global fuera de una justicia cognitiva global (implicando tanto a la justicia epistémica como a la justicia ontológica). No obstante, si tomamos con seriedad "el giro ontológico" de la antropología y otras disciplinas y su enfoque en las ontologías indígenas, pareciera que llegamos a una situación analítica difícil de manejar en relación a las nociones convencionales de justicia climática. De esta manera, analizando el cambio climático en relación a ontologías múltiples, nos encontramos frente a dos riesgos: 1) el de reproducir lo que denomino "la colonialidad de la realidad" que no es sino la idea de que las ontologías indígenas no son más que (mis-) representaciones culturales del mundo; 2) el riesgo de reproducir un relativismo conservador que no hace nada más que mantener el estatus quo y que lleva cierta semblanza con la posición de la negación del cambio climático antropogénico. Empero, la apreciación etnográfica profunda de lo que llamo "la meteorología moral" en los Andes y una comprensión más amplia del cambio climático nos permiten navegar entre la Escila de la colonialidad y el Charibdis del relativismo y así articular una crítica radical del capitalismo fósil desde una ontología relacional, simultáneamente exigiendo justicia climática y denunciando la colonialidad, analizando así la ontología política del cambio climático sin omitir su ecología política y viceversa.

Palabras claves: Colonialidad; justicia climática; justicia cognitiva; ontología política; ecología política; Aymara.

\section{Introduction}

It has been convincingly argued by Portuguese thinker Boaventura de Sousa Santos that there is no global social justice without global cognitive justice (Santos, Arriscado Nunes and Meneses 2007: ixx). In this article I build on this assertion and suggest that there is no global climate justice without global cognitive justice. Though seemingly plain, such a claim may prove to be quite problematic, because if we take it seriously, and if we understand cognitive justice as holding both epistemological and ontological properties, we seem to end up in a situation that is difficult to maneuver in relation to climate justice.

Four quotes from the Andean context in which my research is situated introduce the problem at hand. The first quote comes from an indigenous Aymara regional leader in his thirties living in a small community on the shores of Lake Titicaca, Bolivia. He explained the reasons behind climate change to me thus when we met in May 2015:

It was different before. There was a time for sowing, a time for harvesting. Not now. Nowadays it comes later in the year in some places, and earlier in other places. There is climate change, and it worries us. And we discuss it. It shouldn't be raining now for example. It usually rains in December, January, but now the rains have continued, and there have been hail and frost. Our grandparents always said that we always have to ask our Mother Earth for permission to sow, to harvest. But a lot of these things have been forgotten. And it must be so, that this is why these things happen. There has really been a climate change.

The second quote comes from an urban middle class environmentalist activist also in his thirties, whom I interviewed in downtown La Paz in March 2017. When asked about the reasons behind Bolivia's increasing levels of greenhouse gas emissions, he told me:

On the one hand, we have a government that talks about the rights of Mother Earth and Pachamama and about anti-imperialism, but at the same time they are deforesting the Amazon. They say they want development in harmony with Pachamama, and they legitimize it all by saying that they are an indigenous government. But they really don't know what sustainability means. On the other hand, we have poor peasants who have lost the knowledge of cultivating the land in sustainable ways. They are not really indigenous people anymore, because they exploit the land. These are our principal contributions to global climate change. 
The third quote comes from an urban middle class activist in her forties who participated at a climate justice meeting in the more affluent parts of La Paz in February 2015. Addressing what has become perhaps the most emblematic expression of climate change in the Andes, i.e. melting glaciers, she emphasized quite different processes behind climate change:

The glacier Chacaltaya is melting because it's so close to the city of El Alto which emits heat because people have tin roofs instead of green plastic roofs, and in the past people removed enormous amounts of ice from Chacaltaya to keep their meat cold, there were no refrigerators then. (---) In the mining villages the schools are empty. The kids will become mineworkers anyway. Mineworkers are not interested in the environment, what interests them is money. Coca farmers cut down forest to earn money, they're happy and don't do anything. And the workers, they earn well and are happy with the government's politics. That's why it's so difficult to get these sectors to work with us [on climate change]. What we have is a middleclass that is active in discussing these issues.

And then her fellow activist, an urban middle class woman in her thirties, added:

People in the villages have no idea about climate change. They live in the deepest ignorance regarding these issues. How is it possible that they don't have the slightest idea about climate change and the environment?

In all four cases it is people of indigenous origin, whether they are rural small-scale farmers, mineworkers or urban residents in the largely indigenous city of El Alto (or even government officials), who are identified as being responsible for climate change on a national level or for being a problem in addressing climate change. Their respective grounds for identifying the practices of Andean indigenous people as a problem are quite different, however. In the first case, the Aymara leader points to the fact that traditional ritual practices related to agriculture have been abandoned; in the other three cases urban activists point to the supposed ignorance and lack of education among indigenous people.

By all means, blaming fulfills a function; it allows people to make sense of risk and address it accordingly (Douglas and Wildavsky 1982; Eguavoen 2013: 7). From a climate justice perspective, however, this relative and supposed mutual understanding of who is to blame is problematic. Since ecological and carbon footprints and levels of income have proved to be highly correlated (e.g. Kuzyk 2011), it's reasonable to assume that the greenhouse gas emissions of a person with a middle class lifestyle in the city of La Paz are much higher than those of a small scale farmer or a low-income worker in the city of El Alto. And just like access to economic capital implies a higher capacity for displacing environmental loads to people and ecosystems beyond one's horizon (Hornborg 2009), so does access to a certain cultural and discursive capital entail a higher capacity for displacing responsibilities, in this case for climate change, to less privileged actors.

However, while the actors above may seem to agree on who is the culprit or who's the problem, the rural Aymara leader and the urban activists are arguably not discussing the same thing. And while the urban activists might be criticized for blaming less privileged actors while exculpating their own social class, how do we understand Aymara people blaming themselves for climate change? As a simple misunderstanding? As curious ethnographic data? I think not.

A general so-called "ontological turn" in the social sciences (Descola 2013; Escobar 2007; Venkatesan 2010) has insisted on taking radically different ontologies seriously, and Mario Blaser (2013, 2014), Marisol de la Cadena $(2014,2015)$ and others have drawn our attention to the asymmetries of power that are inherent in inter-ontological relations. This article is written as a contribution to this debate on the "politics of ontology" (Holbraad, Pedersen and Viveiros de Castro 2014) or, in Blaser's (2013) words, "political ontology." Nevertheless, discussing climate change in relation to multiple ontologies, implies two risks: 
1) the risk of reproducing what I call "the coloniality of reality", arguing that indigenous ontologies are actually nothing but cultural (mis-)representations of the world while hegemonic scientifically grounded explanations are the only true and exhaustive accounts of the only real reality there is;

2) the risk of reproducing a conservative relativism that obstructs the theorization of power and that therefore might be instrumental to the conservation of fossil-fueled capitalism and that may even bear a resemblance to climate change denial.

How do we take radically different understandings of climate change seriously without unintentionally articulating an argument that might relativize any claim for climate justice? Or, in other words, how can the political ontology of climate change be discussed without ignoring its political ecology and vice versa?

In this article I argue that a thorough ethnographic understanding of what I call "the moral meteorology" of the Andes and a broadened understanding of climate change make it possible to navigate between the Scylla of coloniality and the Charybdis of relativism. Moreover, Aymara social/racial categories and their foundation in notions of belonging and exploitation are delved into in order to understand how a radical critique of fossil-fueled capitalism may be articulated from within a relational ontology, demanding climate justice while denouncing coloniality. Among the thoughts I want to combine in this endeavor are those of Marisol de la Cadena, Mario Blaser, Boaventura de Sousa Santos, Silvia Rivera, Walter Mignolo, Alf Hornborg, and, not least, Aymara shaman and writer Carlos Yujra. When it gets dim I will use this list of names as a lifeline.

\section{Climate justice and cognitive justice}

As a radical claim from social movements and communities in the global South, climate justice addresses issues of responsibility and debt and the uneven distribution of privileges and risks. As an analytical tool it can be applied to global as well as regional and local scales. The term was popularized by the formation of the "Climate Justice Now!" network in Bali during the $14^{\text {th }}$ UNFCCC Conference of the Parties (COP) negotiations in 2007 and was instrumental in the social mobilizations to make the debate on climate change more explicitly political during the following COPs (Building Bridges Collective 2010: 27). While conceptualized in many different ways (e.g. Forsyth 2014; Shue 2014), one fundamental class of climate justice claims addresses the unequal distribution of burdens. Simon Caney (2014: 125-126) identifies three principles of such "burden-sharing justice":

1) those who have caused the problem should bear the burden;

2) those who have the ability to pay should bear the burden;

3) those who have benefited from the activities that cause climate change should bear the burden.

The three principles, however, tend to conflate into one category of actors and not three, since those who have benefited from the activities that cause climate change also tend to be those who have the ability to pay and those - or descendants of those - who have caused the problem. A just distribution of privileges, risks, burdens and responsibilities, then, is not what characterizes the current world-system. Rather the opposite: those who have caused the problem and have benefited from the activities that cause the problem tend to be less vulnerable to the effects of climate change, while those who have contributed very little to climate change and benefited very little from the activities that cause it tend to be among the most vulnerable to its effects (see e.g. Roberts and Parks 2007).

The injustice, however, does not end there. Not only are those who have contributed least to climate change and benefited least from the activities that cause it among the most vulnerable to climate change, they are also often blamed for it, be they swidden agriculturalists or supposedly ignorant working class people without the "environmentalized" consciousness (Agrawal 2005) that characterizes the ecomodern subject. 
Modifying the concept "environmental load displacement" (Hornborg 2009; Muradian, O'Connor and Martínez-Alier 2002), I call this "environmental blame displacement."

The cry from the global South for climate justice is thus a legitimate cry in a world of unequal distribution of privileges, risks, burdens and culpabilities related to climate change. But there is also another, equally legitimate, cry coming from the global South and especially from indigenous peoples. A cry for cognitive justice. And problems seem to arise when these two different cries for justice are combined. To understand why that is, we need to explore the meanings and implications of cognitive justice.

Cognitive justice, as developed by Santos, is a concept concerned primarily with epistemology, i.e. with knowledge. The European colonial expansion starting in the late $15^{\text {th }}$ century, Santos (2007) argues, implied not only genocide but also epistemicide (see also Grosfoguel 2013). Epistemic violence was an integral part of colonial violence, and epistemic absence was created where epistemic alterity was detected (Santos 2010; Burman 2012, 2016a), be that by killing knowledgeable colonial subjects or by silencing or marginalizing "knowledges otherwise" (Escobar 2007). The current epistemological implications of this colonial legacy have been discussed in terms of the "coloniality of knowledge" (Burman 2012; Grosfoguel 2013; Lander 2000; Mignolo 2000). Coloniality - that which Walter Mignolo calls "the less visible side of modernity" (1999: 236), or "the hidden face of modernity (...) and the condition of its possibility" as de Oliveira Andreotti et al. (2015: 27) put it - outlived colonialism and provides the rationale and justification for the privilege and dominance of Eurocentric systems of knowledge in relation to other ways of knowing the world. Thus, the coloniality of knowledge did not evaporate from the world-system when the former colonies liberated themselves.

Cognitive justice, in the sense of epistemic justice, is therefore a pending task that, according to Santos, starts "from the premise that the epistemological diversity of the world is immense, as immense as its cultural diversity and that the recognition of such diversity must be at the core of the global resistance against capitalism and of the formulation of alternative forms of sociability" (Santos, Arriscado Nunes and Meneses 2007: ixx).

While much has been said on the matter, I believe there is an essential dimension that is missing in the debate on cognitive justice, especially in relation to climate change, climate justice and indigenous knowledge. What is missing is the fundamental discussion about "what there is" and the mechanisms by which a dominant reality imposes itself on other realities. In the debate, epistemological issues tend to be discussed as though they were disembedded from their ontological contexts. However, as "knowledge" cannot be separated from "reality", epistemological queries cannot be separated from ontological ones. Knowledge is not produced in an ontological void. I would therefore add an ontological dimension to cognitive justice, a dimension concerned with the nature of reality. A focus on the "epistemic locus of enunciation" (Mignolo 1999: 241) is, then, complemented by an interest in the "ontological locus of enunciation", i.e. that space from which "worlds otherwise" are engendered (cf. Escobar 2007). Hence, I propose a number of additional questions to be considered in research on indigenous people and climate change: within which ontologically informed lifeworlds and in which relational fields - communities of being - are knowledges about reality produced and by whom? By which mechanisms are the partial connections between different ways of generating and experiencing realities transformed into spaces of conflict, domination and resistance? ${ }^{2}$ These are questions dealing with "what there is", with what kind of actors there are and what kind of human and other-than-human beings compose the relational fields within which knowledge production and political struggle take place, within which climate change is experienced, understood, and addressed, and from within which cries for cognitive and climate justice are raised. Cognitive justice, then, would not only be about whose knowledge is allowed to count as legitimate knowledge (a critique of the coloniality of knowledge), but also about whose reality is allowed to be real (a critique of the coloniality of reality).

\footnotetext{
${ }^{2}$ Elsewhere, I discuss a similar question in relation to knowledge production in higher education (Burman 2016a).
} 


\section{Moral meteorology}

Friedrich Nietzsche (2005[1878]: 181) once wrote that the reason for why people like to be out in nature is that it has no opinion about us. Nature would be that liberated sphere in which we're relieved of the others' gaze and judgments. Though a passionate hiker and a lover of the "air of the heights" (2004[1908]: 8), Nietzsche obviously never trod Andean soil. In the Andes, die freie Natur offers no place for "azure solitude" (ibid: 74). In an animate landscape of other-than-human subjectivities with agency, intentionality, power, and an avid will to communication, mountains, plains, rocks, lakes, and streams tend to one's every move.

The animate nature of the Andean landscape stems from it being saturated with ajayu. The ajayu is a prerequisite and a requirement for all varieties of being. Where there is life, agency and subjectivity, there is ajayu. "Everything has ajayu, even textiles, even music, even stones, even the stars" as Aymara shaman Carlos Yujra says. Ajayu may be translated as "spirit"; however, it is not a Cartesian "ghost in the machine" and, clearly, translation involves equivocations (Viveiros de Castro 2004) and the comparability of "ajayu" to "spirit" does not necessarily signify its unproblematic translatability.

The term ajayu has been the subject of quite a number of seemingly contradictory ethnographic studies (e.g. Bastien 1985; Burman 2010, 2016b; Carter 1968; Fernández Juárez 1999; Girault 1988; Huanca 1989; Orta 1999). While there is little disagreement about the notion that the ajayu comprises various essences or qualities, the terminology is disputed. Fernández Juárez (1999: 150ff) tells of "the three shadows" ajayu, animu, kuraji, while Huanca (1989: 11) notes ajayu, jañayu and animu. Carter (1968: 247) discusses five "souls": ajayu, anima, jañayu, q'amasa and coraje, while Orta (1999: 872) writes of ajayu, animu, kuraji and alwa.

Among the Aymara shamans and activists I have worked with for almost two decades, there is a similar diversity of notions related to the ajayu concept. While some speak of qamasa as being more powerful than ajayu and animu, there are others who speak of an ajayu consisting of qamasa, saqapa and jañchi ajayu ("skin ajayu"). There are those who speak of jañayu as the ajayu's "complement", while a few speak of one singular ajayu. Some talk in terms of ajayu and "energía", while others conceive ajayu as spirit, qamasa as courage, and ankayu as nerve. Interestingly, while there are indigenous activists who speak of the existence of one ajayu of "the Aymara nation", the majority of Aymara shamans I have worked with would deny the existence of any such ethnically restricted collective ajayu.

Most ethnographic accounts of the ajayu discuss it as though it was a strictly human issue. Ajayu is, however, not limited to a circumscribed humanity; it is rather what makes humans part of a broader web of being by constituting subjectivity and bestowing agency. Thus, ajayu is what makes all beings persons. Ajayus are all around; they permeate landscapes, territories and places; they infuse being and existence, body and mind. Greater ajayus comprise smaller ones in a hierarchical order ultimately rising to two allencompassing great ajayus, which are sometimes called Pacha Awki ("Father of Cosmos", related to the celestial spheres) and Pacha Tayka/Pachamama ("Mother of Cosmos"/"Mother Earth", related to the telluric spheres) or simply achachilas (grandfathers or male ancestors) and awichas (grandmothers or female ancestors).

For our discussion on climate change, the achachilas (and also some awichas) are of special interest since they control the weather. These ancestral beings do not only inhabit the mountains, they embody the mountains, they are the mountains. The material mountain is the body of the ancestral ajayus. However, there is no definite discontinuity between the spiritual and material features of ajayu and no point at which "body" is entirely detached from "spirit." There is rather a gradual transition from spirit to body and vice versa in which ajayu could be understood as the most intangible degree of body, and body could be understood as the materially most palpable degree of ajayu (Burman 2016b: 110, 117). In other words, while body and spirit are distinct categories, they are not mutually exclusive opposites; there is something of spirit in body, just as there is something imperceptible of body in spirit (Burman 2016b: 111).

Aymara people often refer to achachilas and awichas in terms of ajayu uywiris (breeders/protectors/shepherds). While environmentalists across the globe promote a notion of indigenous peoples as "guardians of nature", it follows from the concept uywiri that Aymara people tend to see themselves as "guarded by nature" rather than "guardians of nature". However, achachilas do not only protect 
and generate life. They can also rage. They can send hail storms and frost, withhold rain or flood the cultivated fields. There are many ethnographic accounts of the ambiguous and Janus-faced character of the achachilas (e.g. Berg 1989; Burman 2016b; Canessa 2012; Carter and Mamani 1989). Moreover, although they symbolically condense "ancientness" and "nativeness", the achachilas are sometimes likened to foreigners because of the power they hold. Likewise, there are mountains that are identified with powerful, high-ranking professionals such as lawyers, medical doctors, priests and policemen (Harris 1995: 14). One example of this is the mountain Sajama, which often is addressed "Doctor Sajama" in ritual rhetoric. In earlier ethnographic accounts (e.g. Mishkin 1940; LaBarre 1948), the capriciousness of these "supernatural beings" were often underscored and Andean people tended to be depicted as trying their best to gain their compassion through ritual practice. However, according to Aymara shamans, there is no capriciousness; achachilas behave in accordance with Aymara notions of reciprocity and morality and the ritual practice of handing over offerings to them is a way of reinforcing reciprocal relations.

Moreover, people also have to live what is understood to be morally sound social lives in community if the achachilas are to establish the conditions for the crops and pasture to grow and the animals to produce offspring. Ethnographic accounts (see e.g. Canessa 2012: 130-131; Carter and Mamani 1989:289ff) show that moral deviations are addressed by the achachilas by causing extreme weather events or by altering the yearly cycle of one cold and dry season roughly from mid-April to October and one warmer and rainy season from November to March, which can have devastating consequences for the crops and the livestock. Abortion - if not dealt with in ritually correct ways - is said to bring lightning bolts to the community, or cause hailstorms or frost that can ruin the year's crops of entire communities. Infidelity causes draught; murder and rape are of no less consequence. Based on continuous ritual practice and notions of appropriate social life, this is the moral meteorology of the Andes.

In August every year, clouds start gathering around the snow-covered peaks of the Bolivian high plateau, and as the achachilas have watched over people's behavior during the year, people now look towards the achachilas. Aymara shaman Carlos Yujra explains why:

Every year in August all the achachilanaka ${ }^{3}$ meet around the highest mountains to choose a new marani för the year to come. The marani is like a president and the other achachilas are like his ministers in a council. They talk about how people have lived their lives, and then they decide who will decide over the weather this year. The weather depends on who is chosen to be marani. It can be drought or frost. They can send hail or rain. Some achachilanaka are worse than others. It all depends on how the humans have lived their lives, and if we have remembered them.

In the Bolivian Andes, there are at least seven major achachilas and awichas who form the "council", each with their respective temperaments and personalities and distinct weather phenomena in wait for the year they are elected marani (mara means year, and marani literally means "place of the year"). Illimani rises 6,438 meters above sea level and watches over the city of La Paz. Illimani is considered a stable and balanced achachila who tend to produce a likewise stable and balanced weather throughout the year and a lot of pasturage for the livestock. Some 40 kilometers to the North-West, towering over the city of El Alto, Qaqajaqi rises 6,088 meters above sea level. While known as Huayna Potosi on official maps and in tourist brochures, due to its impressive white and grey snowcap, Aymara shamans and most rural people call it Qaqajaqi or Qaqaqi, meaning "the greyish person". As marani, Qaqajaqi is a lot less reliable than Illimani. Qaqajaqi sends drought and frost that "burns" the crops. Another 50 kilometers to the North-West stands Illampu, 6,368 meters above sea level. A year under Illampu's authority is harsh and cold, the achachila whipping up dust from the ground with his powerful winds. He can also send snow and frost. Further to the South, rising 6,542 meters above sea level on the Oruro altiplano Sajama is not only the highest mountain in Bolivia, but also a very powerful wind-maker. His winds are characterized not as "viento" (wind) but as

\footnotetext{
${ }^{3}$ Plural form of achachila.
} 
"huracán" (hurricane). He can also send drought. On the Eastern slopes of the Andes stands Uchumachi, 1,677 meters above sea level. Its slopes are not covered by snow, but by subtropical vegetation. Uchumachi is the "father and mother of all plants" says Carlos Yujra. Uchumachi brings neither frost nor winds, but instead heavy rains that can cause flooding. Nevertheless, "the pasturage grows like in the jungle" during the years Uchumachi is marani, says Carlos Yujra.

These five achachilas are the principal mountains that govern the weather. However, achachilas and/or awichas who are embodied in other places than mountains can also be elected marani. Lake Titicaca is one such place. Quta Jaqi means "lake person" and is the name by which Aymara shamans address the awicha and achachila embodying it. When Quta Jaqi, or Qutaqi, is elected marani a wet and rainy year awaits; fields and pastures may be flooded. From an underwater ridge in Lake Titicaca, another powerful being - an awicha, not an achachila - controls the weather when she is elected marani. Her name is Chuqilla. Carlos Yujra and other contemporary Aymara people associate her name with "chuqi", i.e. potato, and "illa", i.e. amulet or spirit concerned with animal fertility and abundance and talked of as "ispalla" when referring to the ajayu of domesticated plants in general and the potato plant in particular. As marani, Chuqilla brings rain and good harvests, but she also sends devastating lightning. Drawing on Berg (1985) and Cobo (1964), Johan Reinhard (1992: 135) writes of her:

Interestingly there is a current belief that a spirit resides on a mountain in the bottom of Lake Titicaca (...). Its name, Chuqilla, may be derived from Chuquiilla, one of the names of the Inca Weather God, Illapa (...). This deity controlled meteorological phenomena and thus, of course, the circulation of water. lllapa shared many similarities with the weather god of the Aymaras in the Titicaca region, who was called Tunupa, and often their names were used interchangeably.

Today, Tunupa is not the "weather god of the Aymaras." Chuqilla, though, is still among the powerful beings that constitute the council that governs the weather, all according to the moral conduct of the people dwelling in their landscape and whether or not they have fulfilled their ritual obligations with the ajayu uywiris. Minor achachilas and awichas - hills, streams, stones and plants - are the major achachilas' and awichas' eyes and ears in the landscape and report back to the council continuously throughout the year. Moreover, at the marani's side is Chimpurachachila, a messenger, a sender of signs to be interpreted. Looking towards the horizon at sunset and sunrise, gazing at the starry night sky and the snow-covered peaks, there are messages for those who know how to read them. Messages, not least, about the weather to come. The shamans see the signs; they perform rituals and ask for forgiveness for any misdeeds committed by the community.

Not only shamans perform rituals, though. People burn ritual offerings in their homes or climb smaller mountains with offerings during the entire month of August. Some explain the intense ritual practice during the month by referring to the new agricultural cycle that is about to begin when the fields are plowed and the seeds are sown in September and October. After a long sleep throughout the cold months of May to July, Pachamama wakes up in August and is hungry and is therefore fed with the scents and smokes from the ritual offerings. According to Carlos Yujra, however, August is not only dedicated to Pachamama:

During the entire month of August, nature fights over who will be government, that's why people do rituals that time of the year. It's not Pachamama's month - that's bullshit. It's not only mother earth, the entire nature is discussing, debating, they are analyzing the humans, how we're living our lives, if there is disequilibrium, they analyze all these things to know if they should punish or not.

Today, according to Carlos, they punish more often than before. There are more extreme weather events and more unpredictable fluctuations in the weather: 
The climate was different before, there are more problems now, and this causes imbalance. Today people are unbalanced, and that's why the climate is unbalanced. When I was a child, the rains came when they should come. Today they don't come when they should, they come any day now. The bad life [la mala vida] causes what they call climate change.

Carlos calls this "pacha usu." Usu means illness or disease. And while "pacha" very well may mean "weather" or "climate", it may likewise mean "time", "space", "and", "earth", "season", "cosmos", all depending on social and semantic context. "Climate illness" would, then, be one possible way of translating pacha usu. However, it would not be equivalent to a modern scientifically grounded understanding of climate change since pacha usu, according to Carlos, is caused by much more than the emission of greenhouse gases in the atmosphere; it also involves pollution ("tóxicos" and "humos") and environmental degradation of different kinds, the mechanization and industrialization of agriculture, the disintegration of rural communities, industrially processed food, and, not least, immoral social behavior, the lack of ritual practice and a more general alienation from the world of the ajayu uywiris. "Pacha" is more than "climate" and, consequently, a conventional understanding of climate change does not exhaust the meaning of pacha usu.

Moreover, pacha usu is not limited to the outer world; also people are sick according to Carlos:

People's breath is toxic, it's because of what we eat nowadays, and all the bad things we speak. And that's why the snow is melting on the mountains. People, the tourists, shouldn't go up there and let their breath fall on the snow.

Modernity, exemplified here in processed foods and immoral speech, makes people ill and this goes for all people, even rural Aymara people, according to Carlos:

It used to be better in the countryside, but not now. Now there are schools in the countryside, there weren't before. Indigenous people remembered nature. Not now.

Formal institutionalized education is, according to Carlos, part and parcel of a disembedding project of modernity which alienates people from the world of the ajayu uywiris and causes illness in the world.

I started this article with a quote by an Aymara leader who identified the lack of ritual practices as the principal cause of climate change, and I asked how to best understand what seemed to be an example of less privileged actors blaming themselves for changes they have contributed very little to. I would argue that a thorough ethnographic understanding of the moral meteorology of the Andes and a broader, less reductionist, understanding of climate change indicate that Aymara understandings of climate change go beyond selfblame. And as we will see below, they reflect a sophisticated notion of climate justice and contain a seed of radical critique of fossil-fueled capitalist exploitation. Nevertheless, this seed is planted in a subalternized lifeworld, a damné reality that has yet to carve out a space for itself in the dominant debate on climate change.

\section{The coloniality of reality}

On August 1 2015, while Aymara people climbed the smaller mountains with offerings and the shamans started looking for signs on the horizon around the snow-capped mountains to forecast the weather of the year to come, the Bolivian climate movement met in the upper middle class neighborhood of Sopocachi to discuss climate justice and the upcoming COP 21 in Paris. This year I choose not to climb the mountains together with family and shamans on August 1 . Instead I jumped on the bus to Sopocachi.

The Bolivian climate movement is a loose and informal network of small groups, communities and organizations, including anything from radical anarchist groups to communities of concerned natural scientists. While indeed heterogeneous, apart from a shared concern for climate change and the government's developmentalist politics, these groups also tend to share a certain discursive and organizational distance to the indigenous organizations and social movements that have redrawn the Bolivian cartography of power 
since the year 2000. While the indigenous social movements - in conversation with a global discourse on indigeneity and a governmentalized discourse of hegemonic indigeneity (Burman 2014) - have forged a rhetoric of their own, the climate movement expresses itself in an idiom more closely related to the discourse of the international development cooperation community and UN climate adaptation policies. The concept "sociedad civil" ("civil society") exemplifies this. To the climate movement, the principal political actor in addressing climate change and claiming climate justice is la sociedad civil. Indigenous social movements tend to talk of "el pueblo" ("the people") or "los pueblos" ("the peoples", meaning indigenous peoples). At the meeting in Sopocachi, an indigenous activist told me: "I don't know what they mean by 'sociedal civil'. I don't even know if they include us in it. And still, if they do, I don't want to be included on their terms." To many Aymara activists and shamans, "climate change" is more related to a certain discourse and certain nonindigenous powerful actors - "la sociedad civil" - than to pacha usu, as discussed above.

While the Bolivian climate movement, then, is a loose and quite heterogeneous network of different actors, it could nevertheless be rather sweepingly characterized as an urban, non-indigenous, middle class movement. Moreover, foreign scholars and activists residing in Bolivia play a non-negligible role in molding the movement's discourse and practices. Still, indigenous delegates are often present at its larger meetings, and quite innovative forms of alliances are currently being forged between urban environmentalist and climate justice organizations and networks such as Plataforma Boliviana Frente al Cambio Climático and Observatorio Boliviano de Cambio Climático y Desarrollo and rural indigenous organizations such as Consejo Nacional de Ayllus y Markas del Qullasuyu (CONAMAQ) and Confederación de Pueblos Indígenas de Bolivia (CIDOB). While their political agendas tend to diverge, these organizations need each other in their opposition to the current government. Their criticism has been directed primarily at the contradictions between governmental discourse and state ceremony and governmental policies and realpolitik, such as using Pachamama as an environmentalist rhetorical device in governmental discourse while implementing developmentalist politics, or speaking of "Vivir Bien" as an "alternative civilizatory paradigm" (Autoridad Plurinacional de la Madre Tierra 2015: 6) while implementing extractivist projects. Likewise, critique has been raised against the fact that "the rights of Mother Earth" have been legally recognized by the Bolivian government while the agricultural frontier is pushed further into the Amazon by state incentives, and deforestation rates and $\mathrm{CO}_{2}$ emissions have reached unparalleled levels (Burman 2016a).

Hence, in opposition to the government, interesting alliances are forged. While such alliances may be one way for oppositional indigenous organizations to carve out a space for themselves in the national debate on climate change and access new political venues, the climate movement is in no less need of the indigenous organizations. In the indigenized political language that currently characterizes Bolivia, to be an indigenous political actor is to be a legitimate political actor (Burman 2014; Canessa 2007). And though the abovementioned contradictions and several corruption scandals, not least the one concerning El Fondo Indígena (see Morales Álvarez 2015), has stained the indigenous legitimacy of the government, to be a "gobierno indígena" is still to be a legitimate government. Moreover, indigenous protesters have emphasized their indigeneity in several social and environmental conflicts lately (Burman 2014; McNeish 2013). For the climate movement, then, indigenous actors provide a certain symbolic value that may be capitalized into political legitimacy.

However, this need to connect with each other is thwarted by ontological difference. Apart from their shared opposition to the government, there is no obvious shared middle ground for conversation between the climate movement and the indigenous organizations. Different notions of "the climate" and "indigeneity" rather tend to collide than to coalesce. Urban climate activists tend to combine a dichotomized notion of nature and society and a focus on issues of global climate change with either a romanticized notion of indigenous peoples as "guardians of nature" or a notion of indigenous people as ignorant climate villains, while the indigenous organizations seem to use widespread concern for climate change as a conduit for struggles for territorial control, where local knowledge of ecosystems, climate, and place is crucial. Moreover, while to the climate activists, climate change is primarily about greenhouse gas emissions, $\mathrm{CO}_{2}, \mathrm{COPs}$, UNFCCC, mitigation, adaptation, benchmarking, the Keeling curve, CDE and INDCs, to many Aymara 
people it's principally about achachilas, awichas, ajayu uywiris, and maranis. ${ }^{4}$ At the meeting in Sopocachi, none of the indigenous delegates were invited as a speaker; rather, they sat in the audience listening to urban activists explaining anything from the Kyoto Protocol to Bolivia's INDC (Intended Nationally Determined Contributions). An Aymara leader told me: "It doesn't matter. They don't listen to us." Not once were Aymara notions of climate change discussed; not once were maranis or achachilas mentioned. Not only is there a difference in idiom, though; there is also a difference in ontology. Within the struggle for climate justice, a low-intensity "ontological conflict" (Blaser 2013) is taking place. Thus, climate change and climate justice in the Bolivian Andes is not only about political ecology, but also about political ontology.

An ontological conflict can be conceptualized in two quite different ways; either as a conflict over the nature of reality, or as a conflict between different realities (Blaser 2013: 548; Burman 2016a: 77). The former conceptualization would imply multiple perspectives on one single reality while the latter would suggest the existence of different worlds, a multiplicity of realities, or a "pluriverse" (Strathern 2004). To think of "realities" in the plural may be problematic since it seems to imply reified and discrete worlds, in which reified, discrete, and mutually excluding ethnic groups or "cultures" would dwell. However, I suggest we think of ontology not as the hermetically sealed property of a circumscribed social group, but as a dynamic configuration of premises regarding the nature of being and reality. Using the concept "pluriversality", Mignolo (2000) points to "the border" as the locus where different worlds meet, not as separate and independent units, but as enmeshed in asymmetrical relations of power, joined, as it were, by coloniality. This way, "reality" is re-conceptualized and transformed from being a monolithic and reified entity, to become transforming and transformative lifeworlds that are multiple in themselves -biophysical and sociopolitical, sociophysical and biopolitical - and the notion of partially connected and partially overlapping realities in the plural become less essentialist and static.

As I have argued elsewhere (Burman 2016a), concrete and situated practices are ways of coming into being in a lifeworld and being brought into being by a lifeworld that is concurrently being brought into being by one's practices, and, certainly, those of others. Blaser (2013) calls this a process of "worlding." It is by no means a solipsistic activity; rather, other powerful actors - be they transnational corporations, states, or ancestral beings such as achachilas - are indeed active in the sociophysical formation of lifeworlds. To climb the Andean mountains with offerings for the ancestral beings is a way of coming into being in relation to these beings, and of making them come into being; a mutual confirmation and unfoldment of relational existences and beings.

In relation to this understanding of "realities", i.e. as ontologically informed lifeworlds, it is evident that ontological conflicts involve asymmetries of power and that they cannot be understood in isolation from the power asymmetries that characterize the world-system, or in Grosfoguel's (2013: 89) words, the "Capitalist/Patriarchal Western-centric/Christian-centric Modern/Colonial World-System." Nor can the relation between the reality that is unfolded by the dominant climate change idiom at the Sopocachi meeting and the reality that is enacted in ritual practice on the mountains be understood separately from these power asymmetries. In the rationalized lifeworld of hegemonic modernity, the encounter of $\mathrm{CO}_{2}$ molecules and the ajayu uywiris is not one of equals. As one specific reality gains dominance, other realities are denied. Hence, the climate justice meeting in Sopocachi does not constitute an ontologically neutral middle-ground, but a middle-ground where not only one specific form of knowledge is given preference, but also one specific reality is naturalized and legitimized, generated and reproduced. Political processes of mobilization and protest are, just like education and knowledge production, not practices that simply reflect a pre-existing reality; rather they contribute to the generation of a specific reality. The realities I refer to in this article, then, are not reified world-objects but rather lifeworlds-in-the-becoming that can be transformed, enacted and unfolded in relation to and by human and other-than-human social and political practices.

As I have argued elsewhere (2012, 2016a), Andean epistemologies have an ontological point of departure in the existence of other-than-human subjectivities and actors, i.e. knowledgeable social subjects and intentional actors with agentive efficacy, such as achachilas. Knowledge about the world is not generated

\footnotetext{
${ }^{4}$ COP (Conference of the Parties); UNFCCC (United Nations Framework Convention on Climate Change); CDE (Carbon
} dioxide equivalent); INDC (Intended Nationally Determined Contributions). 
inside an autonomous human mind that is detached from the known, but in relational fields constituted by human and other-than-human actors. This is where knowledge and meaning is generated - in situated practices and lived experience.

However, based on Cartesian metaphysics and its distinction between the intentional world of human subjects (the knower) and the world of material objects (the known), hegemonic theories of knowledge allow no room for knowledgeable and intentional other-than-human persons. Moreover, hegemonic theories of knowledge suppress any knowledge that is generated from within other lifeworlds, such as the causal chains behind pacha usu, as discussed above. These lifeworlds are the "damnés realities" of the subalternized and racialized Other (Burman 2016a: 85). Fanon (1961) spoke of "les damnés de la terre", or "the wretched of the earth", to explain the existential conditions of those who are located on the darker side of "the colonial difference" (Mignolo 1999), i.e. those who are forced to dwell in the zone of non-being, "the being who is not there" as Nelson Maldonado-Torres (2007: 253) describes it. Damnés realities, then, are the lifeworlds that are not allowed to be, the lifeworlds that are censored by the coloniality of reality.

The damnés realities of the Bolivian Andes - in this case, Aymara lifeworlds - are not, however, the hermetically sealed properties of a discrete and homogenous Aymara people. Rather, these censored lifeworlds have for centuries coexisted, and sometimes merged in creative constellations, with hegemonic notions of the nature of reality. Moreover, during the neoliberal multiculturalism of the 1990s, certain aspects of "indigenous culture" were not only recognized in governmental policy, but celebrated (Burman 2014, 2016b). However, central elements of Aymara lifeworlds - such as other-than-human subjectivities and actors - were recognized, not as notions of reality, but as elements situated on one side of the Cartesian dualism, i.e. as cultural components that project meaning onto the real reality of material objects "out there." This way, "Aymara culture" was reduced to folklore and was perceived as cultural (mis)representations of reality, which allowed institutions of different kinds to rhetorically embrace interculturality and multiculturalism without having their epistemological and ontological foundations transformed by "worlds and knowledges otherwise" (Escobar 2007). The small spaces opened up in the 1990s by neoliberal multiculturalist recognition from above have since then been used by indigenous activists, however, to create new spaces for the generation and proliferation of these censored realities. Currently, from within damnés ontologies and the cracks and fissures in dominant reality, actors carve out new spaces for themselves - not cultural projections but lifeworlds - and the political debate and the climate change debate become spaces of ontological conflicts, in which actors not only speak from different "epistemic loci of enunciation" (Mignolo 1999: 241) but also from different ontological loci of enunciation. Beings from other ontologies are thereby introduced into the dominant political debate and the climate change debate - a process I call "ontological disobedience", discussed by de la Cadena (2010) in terms of "cosmopolitics."

Nevertheless, when indigenous actors introduce ontological notions other than the ones embraced within the coloniality of reality, they would seem to de-fang the critical potential in claims for climate justice. Indeed, how do we articulate a critique of fossil fuel capitalism if the causal chain behind climate change as identified by science is no more and no less objectively and universally real than, say, the autonomous agency of ancestral spirits in Andean mountains? How do we articulate a critique of environmental blame displacement if we simultaneously want to seriously engage with Aymara people's claim that climate change is related to their own lack of ritual interaction with the ajayu uywiris? In the end, the question boils down to how to combine climate justice with cognitive justice, and political ecology with political ontology.

\section{Belonging and exploitation}

At one of our innumerous conversations over the years I asked Carlos Yujra who's responsible for climate change. He gave me a disheartened look and sighed at my ignorance. "We are, Andrés. We are." "Allright" I said "but who are 'we'?" He looked at me again, shook his head and said "We're people [gente], humans. Or do you by chance think the animals live the bad life? No." Carlos made an important distinction here between humans and animals. On the one hand, animals have ajayu and are therefore subjects with agency and intentionality just like humans. On the other hand, they have not alienated themselves from the world of the ajayu uywiris as humans have and are therefore not to blame for climate change or pacha usu. 
Carlos fell silent as though the matter was settled. Humans, "we", are responsible for climate change. We shared some more coca leaves in silence and I started thinking about the notion of an undifferentiated, and therefore unpoliticized, "global we" - as central to dominant narratives of the Anthropocene as it is problematic from a climate justice perspective (Malm and Hornborg 2014). Is Carlos arguing, I thought to myself, that there is such an undifferentiated global human "we" that is equally responsible for climate change? Our conversations had stopped being polite interviews many years ago and rather turned into animated discussions and informal friendly chats, and though my admiration and respect for Carlos' knowledge is profound there was no mannerly deference that held me back from challenging him on this point. "But is everyone responsible?" I asked. "Yes, today almost everyone lives a bad life" he said. "But what about, say, factory owners? " I insisted. "Of course, they are much more responsible. They live a very bad life and they throw toxics [tóxicos] out in nature. They are misti-q'aras" Carlos said and dissipated any suspicion of mine about Carlos uncritically embracing something akin to an undifferentiated Anthropocene narrative. Obviously, beyond the distinction between animals and humans, Carlos makes other distinctions.

One fundamental social distinction that Carlos and many other Aymara people make is the one between jaqi on the one hand and misti-q'aras and rinkus on the other. In this distinction, I would argue, lies the solution to the problem posed at the beginning of this article about how to reconcile claims for climate justice with claims for cognitive justice and how to understand what appears to be less privileged actors blaming themselves for changes they have contributed very little to.

The social categories jaqi, misti-q'ara and rinku are, in a sense, racial categories. However, they are dynamic, unfixed and based on everyday practices and livelihood rather than on any inherent essences. "Race" in the Andes is anything but stable. To equate jaqi with "indian" or "Aymara" and q'ara with "white" in any plain way is simply wrong since it comes out of assuming that "race" in the Andes is constituted in the same way as race in Europe, and it is not (see e.g. Canessa 2012: ch. 5). "Race" in the Andes is primarily about social and ritual practice, livelihood, belonging, and exploitation. You can be born into a family of jaqi and still die as a q'ara. You cannot be born as jaqi, though, since jaqi is something you become. To be jaqi is to be a married adult and a social person within the moral economy of the community. While Aymara communities display internal hierarchies and divisions just as much as, or even more than, egalitarian communitarianism, to be jaqi is fundamentally about sociality, morality, and community belonging, about the redistribution of wealth within the community and about the importance of community responsibilities and offices, so called "cargos". Jaqi live off their own labor and, of fundamental importance here, their livelihood and their very existence is intimately bound up in reciprocal relations with the ajayu uywiris (Canessa 2012: ch. 4-5). Without such relations no well-being would be possible, no crops would grow and no livestock would reproduce. When jaqi fail to fulfill their ritual responsibilities, the ajayu uywiris respond with extreme weather events and unpredictable weather fluctuations, as discussed above.

"Misti" is simply the Aymara term for "mestizo." Mistis are not jaqi; they are more associated with q'aras and some, as Carlos Yujra, conflate the two categories into one: misti-q'ara. Q'ara is fundamentally the Aymara term used for Bolivians of European descent or anyone behaving like one. Being of European descent in a racialized society means being privileged. It means being economically and politically privileged, but it also means having access to a cultural and discursive capital that enables, for instance, environmental blame displacement, as discussed above. Q'ara literally means "peeled" and its meaning is often explained by Aymara people with an anecdote about how the Spaniards came to what is now Bolivia "without anything, no women, no belongings, no land", i.e. peeled. The dominant are socially and culturally "peeled" or, to speak with Giddens (1990), "disembedded." More importantly still, they are exploiters, it is argued, who live off the labor of others; they have nothing that is fruit of their own labor and they are not part of the moral economy of the community of jaqi. As the concept of jaqi is based on notions of sociality and morality and on the importance of community responsibilities, Aymara people who do not fulfill their responsibilities, who accumulate riches and who live off the labor of others can be accused of being q'aras (and hence of not being jaqi). Q'aras have no ritual obligations to fulfill with the ajayu uywiris; their livelihood, their well-being and affluence is not based on any reciprocal relations with the ajayu uywiris, but on the brute exploitation of the labor of others. While the ajayu uywiris react forcefully to any lack of ritual retribution from jaqi, the fact that q'aras do not maintain any reciprocal relations with them is a non-issue. There have simply never been any 
ritual relations to maintain and the ajayu uywiris play no role whatsoever in the creation of the affluence of the q'aras.

Rinku is the Aymara pronunciation of "gringo", the European or North American foreigner. Rinku is an external, and therefore seemingly irrelevant, actor in Aymara social/racial categorization, but there are those, as Carlos Yujra, who identify rinkus as people who hold the position of the q'ara, i.e. the disembedded exploiter, on a global scale. ${ }^{5}$

Hence, there are two different ways of creating well-being and material affluence. One way is to live off one's own labor within the moral economy of the community and to maintain reciprocal relations with the ajayu uywiris. The other one is to exploit the labor of others. The latter implies not being part of the moral economy of the community and not being enmeshed in any reciprocal relation with the other-than-human actors embodied in the Andean landscape. Depending on whether one practices the first or the latter obviously not a simple choice of one's own -, one is either jaqi or q'ara.

It is against this background of Aymara social/racial categorization and understandings of exploitation, that the quote of the Aymara leader at the beginning of this article can be comprehended as something that goes beyond self-blame of the less privileged and rather constitutes a quite sophisticated notion about the "common but differentiated responsibilities" for climate change, as stated in the Rio Declaration. Q'aras are not part of the moral economy of the Aymara community and not part of the reciprocal relations with the ajayu uywiris, and it's therefore not even worth mentioning that their practices contribute to pacha usu; it's all too obvious. As there are two ways of creating well-being and affluence, there are two ways of causing pacha usu. One within, and one without. Few Aymara people would dispute Carlos' claim that misti-q'aras "throw toxics out in nature" and that this affects pacha as a whole in detrimental ways. Nevertheless, few would argue that changes in the social life of the communities and the abandonment of certain ritual practices have nothing to do with it.

Hence, when the climate activists and the Aymara leader who were quoted at the beginning of this article seem to agree on who's the culprit or who's the problem in addressing climate change on a national level, their concordance is only apparent, and not only because the ontological premises of their respective quotes differ. The Aymara leader's quote involves a more critical judgement than it seems, and goes beyond self-blame. Q'aras and rinkus are not part of the moral economy of the community and ritual reciprocity and are thereby, by implication, to be blamed because their affluence is based on exploitation, and exploitation is by definition "bad life", or as Carlos calls it in Aymara "jan wali jakaña." Jaqi who bring climate change to the local community by immoral actions or by disrupting the ritual interchange with the ajayu uywiris are blamed because they act like q'aras or rinkus. They live "the bad life."

\section{Concluding remarks on political ecology, ontology, and power}

To involve powerful other-than-human persons in the debate on climate justice is, I have argued, an exercise in ontological disobedience, which implies not accepting that reality can be reduced to that which powerful actors allow to exist. That which is not allowed to exist is also there, as potentially emergent realities (see Santos 2012). These are the damnés realities. And they should not be understood without the colonial capitalist world-system, but rather, in spite of it (see Blaser 2013). They are realities with the potential to challenge coloniality/modernity and to engender alternatives; they are realities that house a systematic critique of fossil-fueled capitalism and the coloniality of reality.

The damnés realities revindicated by Aymara shamans and activists and the dominant reality generated and reproduced within the Bolivian climate movement are neither discrete ontologies that people move between as they like, nor do they necessarily merge into a hybrid fusion. They rather overlap and interconnect in a myriad of power-infused ways and are simultaneously present in peoples' practices, experiences, and lifeworlds. Thus, ontological disobedience does not imply the revindication of a hermetically sealed

\footnotetext{
${ }^{5}$ Being a rinku myself - but a rinku who has married into urban Aymara society and who is therefore sometimes referred to as tullqa (i.e. "brother-in-law") - my position as a researcher here is complex. The extent to which my relative otherness by implication reproduces the coloniality of knowledge in the research process and the prospects for decolonial ethnographic research practices are issues I deal with elsewhere (Burman 2016b).
} 
precolonial indigenous world. Rather, drawing on Silvia Rivera (2012), I would argue that ontological disobedience is a ch'ixi practice in a ch'ixi reality. An Aymara dictionary will tell you that "ch'ixi" means "spotted" or "grey". There is much more to this seemingly trivial concept, though. That which is ch'ixi may seem one greyish blend to the human eye, but the color is actually constituted by tiny black and white spots. Rivera uses this concept to discuss how elements from different cultural and cosmological contexts coexist in social practices and identities. These elements do not merge completely, but exist side by side to form a whole. For instance, the disembedding forces of modernity are present in $21^{\text {st }}$ century Bolivian society alongside the embedding relational forces and notions of "community"; $\mathrm{CO}_{2}$ molecules and maranis, INDCs and achachilas exist side by side in the warming world of the Bolivian Andes. To speak of reality as ch'ixi or of a ch'ixi ontology is, then, to underscore the miscellaneous nature of reality and the coexistence without complete fusion of elements from, as it were, different realities in one and the same lifeworld.

While the so-called ontological turn has made a significant imprint on the theoretical debate in social and cultural anthropology, political ecology as a research field has, with some notable exceptions (e.g. Blaser 2010; Escobar 2010; Pellizoni 2015; Schulz 2017; Sullivan 2017), been less receptive to what Marisol de la Cadena (2014) calls "the ontological opening." There is a reason for this. Although indigenous knowledges and lifeworlds may be interesting to anthropologists and political ecologists alike, the framing of the debate in terms of "multiple realities" may obstruct the theorization of power and global inequalities, which renders it less attractive to many political ecologists. As convincingly argued by Alf Hornborg (2015: 52), the prospects for theorizing power might indeed seem poor if there is no objective, universal reality or nature out there. Again, if the autonomous agency of achachilas and their power to change the climate are as objectively and universally real as the causal chain of climate change as identified by science, how do we articulate a critique of fossil-fueled capitalism? If we take pacha usu seriously, how do we articulate a claim for climate justice?

These are indeed crucial questions, and Alf Hornborg (2015, footnote 19) has argued that rather than "immersing ourselves in alternative ontologies and denying the reality of 'a common world"' scholars would do well to contemplate global material inequalities. Indeed, an apolitical rumination of ontological multiplicity offers quite meager prospects for critically addressing social and climate injustice. However, I cannot help asking if there is necessarily a contradiction between taking indigenous ontologies seriously and a concern for social and climate justice. In order to contemplate and address global inequalities, do we necessarily need to abandon the project of engaging thoroughly with ontological claims that do not fit within dominant reality? Do we need to reproduce the coloniality of reality in order to address climate justice and the concerns of political ecology? I would argue that the discussion above concerning moral meteorology, race and exploitation, shows that the critical attention to material power asymmetries that is at the core of political ecology may be rewardingly combined with a critical attention to the ontological power asymmetries that underpin such unequal material flows. Moreover, it shows that a radical critique of the climate injustice of the colonial capitalist world-system can be articulated from ontological premises other than the ones underpinning and sanctioned by that very world-system.

Cognitive injustice and material injustice are, I would argue, dialectically connected in the sense that the former provides a justification and a naturalization of the latter, and the latter is a material expression of the former. The coloniality of reality is the diligent companion of the commodification of reality and the reproduction of consumer society. This is so because modernity, coloniality, and capitalism produce certain subjectivities and a certain dominant reality within which such subjectivities are molded. Ontological disobedience - as practiced by Aymara shamans and activists - is about carving out spaces for the generation of other realities within which other subjectivities may unfold while relations of production and consumption are transformed. Thus, the concerns of political ontology, i.e. the uneven distribution of, as it were, ontological weight, and the concerns of political ecology, i.e. the uneven distribution of environmental burdens and privileges, are not mutually exclusive domains of inquiry, but rather interconnected and overlapping dimensions of global injustice.

\section{References}

Agrawal, A. 2005. Environmentality: technologies of government and the making of subjects. Durham NC: Duke University Press. 
Autoridad Plurinacional de la Madre Tierra 2015. Política plurinacional de cambio climático. La Paz: Autoridad Plurinacional de la Madre Tierra.

Bastien, J. 1985(1978). Mountain of the condor: metaphor and ritual in an Andean ayllu. Long Grove: Waveland Press.

Berg, van den, H. 1985. Diccionario religioso aymara. Iquitos: CETA.

Berg, van den, H. 1989. La tierra no da así no más: los ritos agrícolas en la religión de los aymaras cristianos de los Andes. Amsterdam: CEDLA.

Blaser, M. 2010. Storytelling globalization from the Chaco and beyond. Durham: Duke University Press.

Blaser, M. 2013. Ontological conflicts and the stories of peoples in spite of Europe: Towards a conversation on political ontology. Current Anthropology 54(5): 547-568.

Building Bridges Collective 2010. Space for movement? Reflections from Bolivia on climate justice, social movements and the state. Leeds: Building Bridges Collective.

Burman, A. 2010. The strange and the native: ritual and activism in the Aymara quest for decolonization. Journal of Latin American and Caribbean Anthropology 15(2): 457-475. Researchgate

Burman, A. 2012. Places to think with, books to think about: Words, experience and the decolonization of knowledge in the Bolivian Andes. Human Architecture 10(1):101-120.

Burman, A. 2014. Now we are indígenas! Hegemony and indigeneity in the Bolivian Andes. Latin American and Caribbean Ethnic Studies 9(3): 247-271. Researchgate

Burman, A. 2016a. Damnés realities and ontological disobedience: notes on the coloniality of reality in higher education in the Bolivian Andes and beyond. In Grosfoguel, R., E. Rosen Velasquez, and R.D. Hernandez (eds.) Decolonizing the Westernized university from within and without. Lanham, MD: Lexington Books. Academia

Burman, A. 2016b. Indigeneity and decolonization in the Bolivian Andes: ritual practice and activism. Lanham, MD: Lexington Books.

Canessa, A. 2007. Who is indigenous? Self-identification, indigeneity, and claims to justice in contemporary Bolivia. Urban Anthropology 36(3): 195-237.

Canessa, A. 2012. Intimate indigeneities: race, sex, and history in the small spaces of Andean life. Durham and London: Duke University Press.

Caney, S. 2014. Two kinds of climate justice: avoiding harm and sharing burdens. The Journal of Political Philosophy 22(2): 125-149.

Carter, W. 1968. Secular reinforcement in Aymara death ritual. American Anthropologist 70(2): 238-263.

Carter, W. and M.P. Mamani 1989. Irpa Chico: Individuo y comunidad en la cultura aymara. La Paz: Editorial Juventud.

Cobo, B. 1964(1652). Historia del Nuevo Mundo. Madrid: Biblioteca de autores españoles.

de la Cadena, M. 2010. Indigenous cosmopolitics in the Andes: conceptual reflections beyond 'politics'. Cultural Anthropology 25(2): 334-370.

de la Cadena, M. 2014. The politics of modern politics meets ethnographies of excess through ontological openings. Theorizing the contemporary, Cultural Anthropology website January 13, 2014. http://www.culanth.org/fieldsights/471-the-politics-of-modern-politics-meets-ethnographies-of-excessthrough-ontological-openings

de la Cadena, M. 2015. Earth beings: ecologies of practice across Andean worlds. Durham NC: Duke University Press.

de Oliveira Andreotti, V., S. Stein, C. Ahenakew and D. Hunt 2015. Mapping interpretations of decolonization in the context of higher education. Decolonization: Indigeneity, Education and Society 4(1):21-40.

Descola, P. 2013. Beyond nature and culture. Chicago: University of Chicago Press.

Douglas, M. and A. Wildavsky 1982. Risk and culture: an essay on the selection of technological and environmental dangers. Berkeley: University of California Press.

Escobar, A. 2007. Worlds and knowledges otherwise: the Latin American modernity/coloniality research program. Cultural Studies 21(2-3):179-210. 
Escobar, A. 2010. Postconstructivist political ecologies. In Redclift, M. and G. Woodgate (eds.) International handbook of environmental sociology, 2nd. Edition. Cheltenham: Elgar.

Fanon, F. 1961. Les damnés de la terre. Paris: Éditions Maspero.

Fernández Juárez, G. 1999. Médicos y yatiris: salud e interculturalidad en el altiplano Aymara. La Paz: CIPCA.

Forsyth, T.J. 2014. Climate justice is not just ice. Geoforum 54: 230-232. Academia

Giddens, A. 1990. The consequences of modernity. Cambridge: Polity Press.

Girault, L. 1988. Rituales en las regiones andinas de Bolivia y Perú. La Paz: CERES/MUSEF/QUIPUS.

Grosfoguel, R. 2013. The structure of knowledge in Westernized universities: epistemic racism/sexism and the four genocides/epistemicides of the Long 16th Century. Human Architecture 10(1):73-90.

Harris, O. 1995. The coming of the white people: reflections on the mythologisation of history. Bulletin of Latin American Research 14(1): 9-24.

Holbraad, M., Pedersen M.A. and E. Viveiros de Castro 2014. The politics of ontology: anthropological perspectives. Theorizing the contemporary, Cultural Anthropology website, January 13, 2014. http://culanth.org/fieldsights/462-the-politics-of-ontology-anthropological-positions

Hornborg, A. 2009. Zero-sum world: challenges in conceptualizing environmental load displacement and ecologically unequal exchange in the world system. International Journal of Comparative Sociology 50(3-4): 237-262.

Hornborg, A. 2015. The political economy of technofetishism: agency, Amazonian ontologies, and global magic. Hau: Journal of Ethnographic Theory 5(1):47-69.

Huanca, T. 1989. El yatiri en la comunidad aymara. La Paz: CADA.

Ingold, T. 2000. The perception of the environment: Essays in livelihood, dwelling and skill. London and New York: Routledge.

Kuzyk, L.W. 2011. Ecological and carbon footprint by consumption and income in GIS: down to a census village scale. Local Environment 16(9): 871-886.

LaBarre, W. 1948. The Aymara indians of the Lake Titicaca plateau, Bolivia. American Anthropologist 50(1). No. 68 of the titles in the memoir series of the American Anthropological Association.

Lander, E. (ed.) 2000. La colonialidad del saber. Buenos Aires: CLACSO.

Maldonado-Torres, N. 2007. On the coloniality of being: contributions to the development of a concept. Cultural Studies 21(2-3): 240-270.

Malm, A. and A. Hornborg 2014. The geology of mankind? A critique of the Anthropocene narrative. The Anthropocene Review 1(1): 62-69.

McNeish, J.A. 2013. Extraction, protest and indigeneity in Bolivia: the TIPNIS conflict. Latin American and Caribbean Ethnic Studies 8(2): 221-242. Researchgate

Mignolo, W. 1999. I am where I think: epistemology and the colonial difference. Journal of Latin American Cultural Studies: Travesia 8(2): 235-245. Scribd

Mignolo, W. 2000. Local histories/global designs: coloniality, subaltern knowledges, and border thinking. Princeton, NJ: Princeton University Press.

Mignolo, W. 2009. Epistemic disobedience, independent thought and de-colonial freedom. Theory, Culture \& Society 26(7-8): 1-23.

Mishkin, B. 1940. Cosmological ideas among the Indians of the Southern Andes. The Journal of American Folklore 53(210): 225-241.

Muradian, R., M. O'Connor and J. Martinez-Alier 2002. Embodied pollution in trade: estimating the 'environmental load displacement' of industrialised countries. Ecological Economics 41(1): 51-67.

Nietzsche, F. 2004(1908). Ecce Homo: how one becomes what one is. In Ecce Homo: how one becomes what one is \& The Antichrist: a curse on Christianity. Translated by T. Wayne. New York: Algora Publishing.

Nietzsche, F. 2005(1878). Human, all too human: a book for free spirits. 9th edition. Translated by R.J. Hollingdale. Cambridge: Cambridge University Press.

Orta, A. 1999. Syncretic subjects and body politics: personhood, doubleness and Aymara catechists. American Ethnologist 26(4): 864-889. 
Pellizoni, L. 2015. Ontological politics in a disposable world: the new mastery of nature. Farnham: Ashgate.

Reinhard, J. 1992. Underwater archaeological research in Lake Titicaca, Bolivia. In Saunders, N. (ed.) Ancient America: contributions to New World archaeology. Oxford: Oxbow Books.

Rivera, S. 2012. Ch'ixinakax utxiwa: A reflection on the practices and discourses of decolonization. The South Atlantic Quarterly 111(1): 95-109.

Roberts, J.T. and B.C. Parks 2007. A climate of injustice: global inequality, North-South politics, and climate policy. Cambridge, MA: MIT Press.

Santos, de Sousa B., J. Arriscado Nunes, and M.P. Meneses 2007. Opening up the canon of knowledge and recognition of difference. In de Sousa Santos, B. (ed.) Another knowledge is possible: beyond Northern epistemologies. London: Verso.

Santos, de Sousa, B. 2010. Epistemologías del sur. Mexico: Siglo XXI.

Santos, de Sousa, B. 2012. Public sphere and epistemologies of the South. Africa Development 37(1):43 - 67.

Schulz, K.A. 2017. Decolonizing political ecology: ontology, technology and 'critical' enchantment. Journal of Political Ecology 24: 125-143.

Shue, H. 2014. Climate justice: vulnerability and protection. Oxford: Oxford University Press.

Strathern, M. 2004. Partial connections. Walnut Creek, CA: Altamira.

Sullivan, S. 2017. What's ontology got to do with it? On nature and knowledge in a political ecology of the 'green economy'. Journal of Political Ecology 24: 217-242.

Venkatesan, S. (ed.) 2010. Ontology is just another word for culture: Motion tabled at the 2008 meeting of the group for debates in anthropological theory, University of Manchester. Critique of Anthropology 30(2):152-200.

Viveiros de Castro, E. 2004. Perspectival anthropology and the method of controlled equivocation. Tipití 2: 322. 